\title{
The 52-Week High And The January Effect
}

Seung-Chan Park, Adelphi University, USA

Sviatoslav A. Moskalev, Adelphi University, USA

\begin{abstract}
The predictive power of past returns for January reversal is compared with that of the nearness of current prices to the 52-week high. When compared jointly, past returns lose their forecasting power for January returns and the nearness of current prices to the 52-week high assumes the dominant role in explaining the January reversal. This suggests that tax-loss selling is not the primary factor explaining the January effect. A behavioral explanation consistent with the window-dressing argument is proposed in that the 52-week high acts as an "anchor," a highly visible reference price to fund holders, increasing fund managers' incentives to window-dress by temporarily adding (removing) stocks that are perceived by fund holders as good (bad) investments, based on the nearness of these stocks' current prices to the 52-week high.
\end{abstract}

Keywords: January effect; window-dressing; tax-loss selling; anchoring bias

\section{INTRODUCTION}

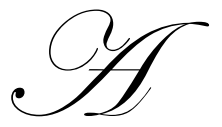

ccording to the efficient market hypothesis (henceforth EMH), all available information is incorporated in security prices and, therefore, public information should not be useful to investors for generating abnormal profits. However, some researchers have contested the EMH by finding investment strategies, i.e., anomalies, which allow investors to generate statistically significant arbitrage profits using publicly available information.

One such anomaly is the "turn-of-the-year" effect (henceforth the January effect), which is a phenomenon whereby stocks generate unusually high returns in early January. This has been the most widely studied anomaly, beginning with Rozeff and Kinney (1976) who were the first to document that average equity returns are higher in January than in any other month. Subsequently, researchers found that this effect is larger for smaller firms, as measured by market capitalization (e.g., Banz (1981), Reiganum (1983), Keim (1983), Roll (1983), Branch and Chang (1990)), and for firms with poor performance in the previous year (e.g., De Bondt and Thaler (1985 and 1987)).

Market microstructure effects important for smaller and lower priced stocks, which might potentially contribute to the January effect, have been thoroughly investigated (e.g., Roll (1981 and 1983), Blume and Stambaugh (1983), Stoll and Whaley (1983), Bhardwaj and Brooks (1992)). The extent of this effect has been studied in fixed income instruments and fixed income funds (e.g., Fama and French (1993), Chang and Pinegar (1986), Maxwell (1998), Starks, Yong and Zheng (2006)), equity mutual funds and index funds (e.g., Booth and Keim (2000), Hensel and Ziemba (2000), Rendon and Ziemba (2005)) and in markets outside of the U.S. (e.g., Gultekin and Gultekin (1983)). Researchers have found that the impact of this anomaly has decreased over time. While Mehdian and Perry (2002) and Gu (2003) reported that the January effect has decreased in major U.S. markets since 1987, Siegel (2007) argues that there has been a resumption of the effect since 2000. Riepe (1998) emphasized an overall increase in investor awareness of the effect during the 1980s and 1990s.

Two important explanations of the January effect proposed in the literature are tax-loss selling and window-dressing. According to the tax-loss selling explanation, investors sell securities in which they incurred losses during the year in order to reduce their capital gains taxes. This activity leads to price declines for losing stocks just before year-end and recovery in January as investors return to these stocks, generating large January returns. Such investor behavior has been examined extensively (e.g., Branch (1977), Slemrod (1982), Chan (1986), Lakonishok and Smidt (1986), Ritter (1988), Dyl and Maberly (1992)), and it has been documented that stocks that 
declined in December had substantial abnormal volume in December and also generated high returns in January (e.g., Dyl (1977), Givoly and Ovadia (1983), Reinganum (1983), Chen and Singal (2004)).

However, a number of studies provide empirical evidence somewhat contradictory to the tax-loss selling argument. For example, Reinganum (1983) showed that small stocks that did not decline in December also had abnormally high returns in January. Jones, Pearce, and Wilson (1987) documented the existence of the January effect prior to the imposition of income taxes in the U.S. Van den Bergh and Wessels (1985) identified the January effect in markets without capital gains taxes, and Brown, Keim, Kleidon and Marsh (1983) and Fountas and Segredakis (2002) documented large January gains in countries where the tax year for individuals was not the calendar year.

The primary alternative explanation of the January effect is the institutional window-dressing argument proposed by Haugen and Lakonishok (1988). This argument maintains that portfolio managers have incentives to sell poorly performing stocks in their portfolios before the end of the year in order to enhance the attractiveness of the portfolio to fund holders. The incentive to window-dress is greater when a portfolio manager's annual performance is compared to peers' performance or when annual statements to investors show individual returns for each stock held in addition to the portfolio's overall return.

Researchers have found that selling losers, as opposed to buying winners, is a more typical form of window-dressing (e.g., Lakonishok, Shleifer, Thaler and Vishny (1991), He, Ng and Wang (2004)). Lakonishok, Shleifer, Thaler, and Vishny (1991) documented window-dressing behavior by pension fund managers. Musto (1997) identified the turn-of-the-year effect among money market instruments, which cannot be attributed to tax-loss selling because money market instruments do not generate capital losses. While Maxwell (1998) and Chang and Pinegar (1986) found evidence of window-dressing activity in noninvestment grade bonds, no such activity has been identified for investment grade or Treasury bonds. Ritter and Chopra (1989) and Meier and Schaumburg (2004) also provided evidence supporting the window-dressing explanation. However, O'Barr and Conley (1992) pointed out that certain types of funds, like internally managed pension funds, university endowments and foundations, place minimal emphasis on short-term performance so that managers of such funds have little or no incentive to windowdress their portfolios.

One of the major difficulties in determining which of the two effects, tax-loss selling or window-dressing, drives the January anomaly is researchers' inability to distinguish individual trades from institutional trades, and taxmotivated trades from other trades. Researchers have studied individual investor trades in order to verify the taxloss selling explanation of the January effect by examining the effects of previous stock returns on end of year trades, and, subsequently, on January returns (e.g., Badrinath and Lewellen (1991), Dyl and Maberly (1992), Grinblatt and Keloharju (2001), Odean (1998), Ritter (1988, 2004), and Ivkovic, Poterba, and Weisbenner (2005)). Additionally, by studying closed-end municipal bond funds, which are held exclusively by individual investors who are particularly sensitive to income taxes, Starks, Yung and Zheng (2006) found support for the view that tax-loss selling is the driver of the January effect. Lastly, Sikes (2008), who used unique data allowing her to separate institutional investors with incentives to realize losses for tax purposes and no incentive to window-dress, and those with incentives to window-dress and no incentive to realize losses for tax purposes, found support for the position that tax-loss selling is the primary cause of the January effect.

Our study contributes to a resolution of the above debate by introducing the ratio of stocks' current price to the 52-week high in order to predict January returns. We compare the predictive power of this ratio to that of stocks' past cumulative returns, a standard variable used to explain the January effect. While the ratio of current price to 52-week high has been used in the momentum literature (e.g., George and Hwang (2004), Park (2009)), to the best of our knowledge, it has not been previously used to analyze the January effect.

Our results document that, not only do past returns have weaker predictive power for January returns than do the 52-week high ratios, but also that the predictive power of cumulative returns disappears once we control jointly for both variables in Fama-MacBeth type regressions. Additionally, we find that when sorting by 52-week high ratios, the January return reversal is driven by both high January performance of stocks with low 52-week high ratios and poor performance of stocks with high 52-week ratios. However, when based on sorting by past 
cumulative returns, the January return reversal is driven primarily by high performance of stocks with low past cumulative returns.

We believe the 52-week high ratio acts as an "anchor," a highly visible reference price for fund holders. Fund managers are aware of this anchor and have incentives to window-dress their portfolios by temporarily adding or removing stocks that are perceived by fund holders to be good or bad investments, based on these stocks' 52week high ratios prior to the end of the reporting period. We argue, therefore, that our results are consistent with the window-dressing explanation of the January effect.

George and Hwang (2004) show that the ratio of current price to 52-week high dominates and improves upon the forecasting power of past returns for profits from momentum investing. They argue that traders use the 52week high as an "anchor" when assessing stocks' incremental value due to new information. When good news has pushed a stock's price to, or near, a new 52-week high, traders are reluctant to bid the price of the stock higher even if the information warrants it. On the other hand, when bad news moves a stock's price far from its 52-week high, traders are initially unwilling to sell the stock at prices that are as low as the information implies. Subsequent corrections of these mispricings generate momentum profits.

Similar to George and Hwang (2004), we argue that when good news has pushed a stock's price to, or near, a new 52-week high, then fund holders may perceive it to be a good investment. On the other hand, when bad news pushes a stock's price far from its 52-week high, fund holders view it as a poor investment. Using the 52-week high as an "anchor" when assessing the stock's performance is a bias because fund holders do not rely on the stock's entire cumulative return history, but rather they base their judgments entirely on the highly visible 52-week high reference price.

Fund managers are aware of this cognitive bias and have incentives to window-dress by selling stocks whose December prices are far from the 52-week high, and buying, or continuing to hold, those with December prices near the 52-week high. As a consequence of such activity, prices of losers increase and prices of winners decline in December. In January, after the reporting period has ended, prices reverse.

Since cumulative returns and 52-week high ratios are highly correlated (in Table 1, we report a correlation coefficient of 53 percent), we follow George and Hwang (2004) and Park (2009) and perform similar tests enabling us to claim that 52-week high ratios possess predictive power for January returns, and cumulative returns appear to possess such power because of their correlation with 52-week high ratios. Although we are unable to test directly for the validity of "anchoring bias" as an explanation of the January effect, our finding that the predictive power of cumulative returns for January returns does not survive the inclusion of 52-week high ratios implies that tax-loss selling is not the dominant explanation of the January phenomenon.

The rest of this paper is organized as follows. In the next section we describe our data and test methods. Section 3 presents our results, and section 4 concludes the paper.

\section{DATA AND METHOD}

\subsection{Data}

We use two data samples obtained from the CRSP monthly and daily files for the period December 1960 through December 2008. The first sample includes all stocks traded on the NYSE, AMEX and Nasdaq. The second sample is a screened version of the first where we exclude both stocks priced below $\$ 5$ at the end of the formation period and stocks with market capitalization that would place them in the smallest NYSE decile. We use the screened sample in order to enhance the robustness of our results by eliminating possible market microstructure effects induced by small and low priced stocks. Such screening criteria have been used previously (e.g., Jegadeesh and Titman (2001), Park (2009)) in order to eliminate the impact of small and illiquid stocks on profits from momentum strategies. 


\subsection{Single-Sorted Portfolios}

We construct single-sorted portfolios based on stocks' cumulative returns and 52-week high ratios. Using the CRSP monthly file, we sort all stocks based on their 11-month cumulative return, from January to November, which we define as our formation period. We construct ten equally weighted (decile) portfolios, where Portfolio 1 has the lowest cumulative return (loser) and portfolio 10 has the highest cumulative return (winner).

We also construct 30-40-30 portfolios, where Portfolio 1 consists of the $30 \%$ of stocks with the lowest cumulative return during the formation period and Portfolio 3 consists of the $30 \%$ of stocks with the highest cumulative return. We then measure returns ${ }^{1}$ for the decile and 30-40-30 portfolios during the following January. We repeat this procedure annually, resulting in 48 January returns for each portfolio. The results in Table 2 represent the time-series average of these January portfolio returns over the period 1961 to 2008 . The 30-40-30 portfolios enable us to investigate the extent of the January effect for less extreme portfolios, as compared with the decile portfolios. We conduct these comparisons not only as a robustness check, but also because these portfolios are used in our subsequent Fama-MacBeth type regressions.

Next, we execute the same construction and return measurement procedure where, instead of stocks' cumulative returns, we use the 52-week high ratios. The 52-week high ratio (henceforth 52HR) is defined as the stock's current price divided by the highest price obtained in the last 52 weeks. We calculate the 52HR measure at the end of November. In order to calculate the portfolios' January returns we repeat the same construction and sorting steps as done previously with cumulative returns. All price data are from the CRSP daily file and are adjusted for splits and dividends occurring during the 52-week window prior to the end of November.

\subsection{Double-Sorted Portfolios}

In order to compare the predictive power of previous-year cumulative returns and 52HR for January returns, we construct double-sorted portfolios. These two variables are highly correlated, with correlation coefficient exceeding 50\% (reported in Table 1). If one variable has predictive power for the January effect but the other does not, then the second might appear to have predictive power simply due to the high correlation between the two variables. In order to determine which of the two variables has the stronger predictive power, we adopt the double-sorting procedure from Chordia and Shivakumar (2002) and Park (2009), who encountered a similar problem when comparing the predictive power of two correlated variables for momentum profits.

We construct the double-sorted portfolios in two different ways. First, at the beginning of each January, we sort all stocks based on the previous 11-month return (January through November) into quintiles. Stocks in each quintile are then assigned to one of five equal-size portfolios based on the 52HR calculated using the previous November-end price. We repeat this procedure annually, resulting in 48 January returns for each of 25 doublesorted portfolios. The results in Panel A of Table 3 represent the time-series average of January returns for these double-sorted portfolios. Second, we perform a similar procedure where we first sort stocks based on the52HR and then based on the 11-month returns. These results are reported in Panel B.

These double-sorting procedures may provide a better understanding as to which of the two variables drives the January effect. If the 52HR appears to have predictive power for the January returns simply because it is correlated with previous year cumulative returns, then the difference in returns between the lowest and highest 11month return portfolios within each 52HR quintile should be greater than, and more statistically significant than, the difference between the lowest and highest 52HR portfolios within each 11-month return quintile.

\section{$2.4 \quad$ Fama-MacBeth (1973) Regressions}

In order to simultaneously compare the predictive power of cumulative returns and 52HR for January returns, and after controlling for potential market microstructure and size effects, we implement Fama-MacBeth

\footnotetext{
${ }^{1}$ This is a cross-sectional average of equally weighted returns of all stocks in the portfolio.
} 
(1973) style cross-sectional regressions in a manner similar to George and Hwang (2004) and Park (2009). For each January, we implement a cross-sectional regression as follows,

$$
\begin{aligned}
R_{i t} & =b_{0 t}+b_{1 t} R_{i t-1}+b_{2 t} \ln \left(\text { size }_{i t-1}\right)+b_{3 t} R W_{i t-D}+b_{4 t} R L_{i t-D} \\
& +b_{5 t} 52 H R W_{i t-D}+b_{6 k t} 52 H R L_{i t-D}+e_{i t}
\end{aligned}
$$

where $R_{i t}$ and $R_{i t-1}$ are stock $i$ 's returns in January and the previous December, respectively, $\ln \left(s_{i z} e_{i t-1}\right)$ is the natural logarithm of the market capitalization of stock $i$ at the end of the previous December, denoted as $(t-1)$. We include December returns $\left(R_{i t-1}\right)$ in order to control for monthly return reversal (e.g., Lo and MacKinlay (1990)), which can affect January returns. Similarly, we include December-end size $\left(\ln \left(\operatorname{size}_{i t-1}\right)\right)$ consistent with previous research indicating that small stocks tend to significantly outperform large stocks in January (e.g., Banz (1981)).

All other independent variables are dummy variables which depend on a stock's inclusion in the 30-40-30 portfolios for each strategy. For each dummy variable, the subscript $D$ denotes a one-month gap (December) between the portfolio formation period and the holding period. We exclude December from the portfolio formation period in order to mitigate the impact of monthly return reversal on the coefficient estimates. As a robustness check, we implement our regressions with December included in the formation period as well, and we find that the results are not sensitive to whether December is included in the formation period.

If $D=1$, we construct the 30-40-30 portfolios at the end of November, using either the previous 11-month cumulative returns from January through November or the ratio of November-end price to the highest price obtained during the previous 52 weeks. If $D=0$, we construct the 30-40-30 portfolios at the end of December using either the previous 12-month cumulative returns from January through December or the ratio of December-end price to the previous 52-week high price. When the gap is included $(D=1), R W_{i t-D}$ is assigned the value 1 if stock $i$ belongs to the 30 percent of stocks with the highest previous 11-month cumulative returns (winners) and 0 otherwise; $R L_{i t-D}$ is assigned the value 1 if stock $i$ belongs to the 30 percent of stocks with the lowest previous 11month cumulative returns (losers) and 0 otherwise; 52HRW $W_{i t-D}$ is assigned the value 1 if stock $i$ belongs to the 30 percent of stocks with the highest previous 52HR (winners) and 0 otherwise; $52 H R L_{i t-D}$ is assigned the value 1 if stock $i$ belongs to the 30 percent of stocks with the lowest previous 52HR (winners) and 0 otherwise. When the gap is excluded $(D=0)$, all dummy variables are constructed in the same manner except that values are based on the previous 12 month formation period and the December-end price.

After estimating the coefficients, $b_{l t}$ for $l=0, \ldots, 6$, we calculate $\hat{b}_{4 t}-\hat{b}_{3 t}$ and $\hat{b}_{6 t}-\hat{b}_{5 t}$ to determine January profits for cumulative returns and 52HR sorting procedures, respectively. Finally, the time-series averages of $\hat{b}_{l t}$ 's, $\hat{b}_{4 t}-\hat{b}_{3 t}$ and $\hat{b}_{6 t}-\hat{b}_{5 t}$, and associated $t$-statistics are used to test for the profitability of each of the two investment strategies and for market microstructure effects and size effects.

\section{RESULTS}

\subsection{Summary Statistics}

Table 1 presents summary statistics for our data. A total of 5,021 stocks are included in our unscreened sample. The average 11-month cumulative return is 14 percent with a standard deviation of 57 percent. The average 52HR is 0.75 (with a maximum of 1 because 52HR is a ratio) and the standard deviation is 0.19 . The correlation coefficient between cumulative returns and 52HR is 53 percent. 
Table 1: Summary Statistics

Using CRSP monthly and daily files, at the end of each November, cumulative return over the past 11 months (from January to November) and the ratio of current price to 52-week high (52HR) are calculated for each stock traded on the NYSE, AMEX, and Nasdaq over the period from 1960 to 2008. The cross-sectional mean and standard deviation of the cumulative returns and 52HRs and Pearson correlation coefficient between two variables are estimated. The table presents averages of the cross-sectional averages, standard deviations, and Pearson correlation coefficients throughout the sample period. (\# of stocks means the average of the number of stocks in the sample for each year.)

\begin{tabular}{|c|c|c|}
\hline & 11-month Return & 52HR \\
\hline Mean & $14 \%$ & $0.75(\max =1)$ \\
\hline Standard Deviation & $57 \%$ & 0.19 \\
\hline $\begin{array}{l}\text { Correlation } \\
\# \text { of Stocks }\end{array}$ & & \\
\hline
\end{tabular}

\subsection{Single Sorted Portfolios}

Table 2 presents January returns and profits for the decile and 30-40-30 portfolios (i.e., return difference between losers and winners), based on sorting by prior-year cumulative returns and 52HR, for both the full and screened samples. Our results are consistent with previous research and confirm the existence of a large and statistically significant January effect.

Panel A of Table 2 demonstrates that, in the unscreened sample based on sorting by prior year cumulative returns, the decile portfolios' January returns decrease from 13.38 percent for the lowest decile (P1) to 5.21 percent for the highest decile (P10). The decrease is not monotonic as January returns decrease from 13.38 percent to 4.29 percent for deciles 1 to 7 , but then increase from 4.43 percent to 5.21 percent for deciles 8 to 10 . This result is also consistent with previous literature indicating that, when using prior-year cumulative returns sorting, the January effect is driven more by high performance of loser portfolios than by poor performance of winner portfolios (e.g., DeBondt and Thaler $(1985,1987))$.

The difference in January returns between extreme losers and winners (P1-P10) indicates that the magnitude of the January effect is 8.17 percent. A zero-dollar investment strategy of buying losers (P1) and simultaneously shorting winners (P10) at the closing price on the last trading day of December and holding until the last trading day of January produces a one-month profit of 8.17 cents per dollar of long-short portfolio. This profit is both economically and statistically significant, with a t-value of 4.34 .

The results for the 30-40-30 portfolios (Panel B of Table 2) reveal that, although the magnitude of the January effect is less than that for the decile portfolios (4.59 percent versus 8.17 percent), the return difference between losers and winners is still statistically significant (with t-value 3.83), despite being based on less extreme portfolios. This is an important finding because we use the 30-40-30 portfolios below in the Fama-MacBeth type regressions.

The 52HR sorting procedure produces a greater January effect than that based on the cumulative returns procedure for both the decile and the 30-40-30 portfolios. For the decile-based portfolios, the 52HR generates a 12.44 percent January profit, with a t-value of 5.5, as compared with an 8.17 percent profit for the cumulative returns procedure, whose t-value is 4.34 . Similarly, the 30-40-30 portfolios produce a 7.66 percent January profit, with t-value 5.68, which is also greater than the profit from the cumulative returns procedure, 4.59 percent with tvalue 3.83 .

Tests for differences reveal that the January profit for the 52HR procedure is significantly greater than that for the cumulative returns procedure for both the decile and the 30-40-30 portfolios. The time-series average difference in profit is 4.27 percent (with a t-statistic of 4.94) for the decile portfolios and 3.07 percent (with $\mathrm{t}$ statistic 5.27) for the 30-40-30 portfolios. This large difference is a consequence of the fact that losers perform better under the 52HR procedure than under the cumulative returns procedure, and winners perform worse under the $52 \mathrm{HR}$ procedure than under the cumulative returns procedure. The third column of Panels A and B in Table 2 indicates that, for both the decile and the 30-40-30 portfolios, the difference in January returns between the 52HR procedure and the cumulative returns procedure is positive for loser portfolios and negative for winner portfolios. 
In the screened sample, which excludes both stocks priced below $\$ 5$ at the end of the formation period and stocks with market capitalization in the smallest NYSE decile, the January effect disappears when the portfolios are sorted based on previous year cumulative returns. This strategy produces a statistically insignificant January profit of 1.14 percent, with a t-statistic equal to 1.00 , a result consistent with previous research documenting that the January effect is driven by small capitalization stocks (e.g., Banz (1981), Reiganum (1983), Keim (1983), Roll (1983), Branch and Chang (1990)). Despite this result, the 52HR sorting strategy produces a statistically significant January profit of 2.65 percent with a t-statistic of 2.27. Although the magnitude of the difference is reduced for the 30-40-30 portfolios, these results present a similar picture. The January profit obtained is small and statistically insignificant under cumulative returns sorting (0.94 percent with t-value 1.3$)$, but is larger and statistically significant when portfolios are sorted based on the prior-year 52HR (2.28 percent with t-value 2.97). The timeseries average difference in profit between the two procedures is 1.51 percent with a t-statistic of 2.38 for decile portfolios and 1.34 percent with a t-statistic of 3.01 for the 30-40-30 portfolios.

Table 2 reveals that the January effect is significant and that both sorting strategies are powerful in identifying the effect. We are unable to make definitive statements here regarding which of the two sorting strategies has the stronger predictive power for the January profit, but Table 2 provides results supporting the 52HR sorting procedure. This procedure generated larger January profits in the unscreened sample and it survives the robustness check in which small and low priced stocks are removed. This is an important finding because it shows that the January effect persists not only in small or low priced stocks but also in large stocks, and is perhaps driven by the 52HR ratio. We believe this result has not been previously identified in the literature.

Table 2: Returns on Decile and 30-40-30 Portfolios and Return Differences

Using CRSP monthly and daily file, at the end of each November we construct decile (Panel 1) and 30-40-30-percent (Panel 2) portfolios based on 11-month cumulative return from January to November and 52HR (ratio of November-end price to 52-week high), respectively. Skipping December, we calculate January returns on each portfolio. P1 in Panel A (Panel B) represents the equal-weighted portfolio of stocks with 10\% (30\%) lowest cumulative returns or 52HRs and P10 in Panel A (P3 in Panel B) represents the equal-weighted portfolio of stocks with $10 \%$ (30\%) highest cumulative returns or 52HRs. Average January returns for all portfolios and the return differences between two extreme portfolios (loser - winner) and associated t-values are presented. Also, we present the January return differences between corresponding portfolios based on the cumulative returns and 52HRs.

We use two samples. In the entire sample, we include all stocks from NYSE, Nasgaq, and AMEX from 1960 to 2008 . In the screened sample, we exclude both stocks priced below $\$ 5$ and stocks with market capitalization that would place them in the smallest NYSE decile when we form the portfolios.

\begin{tabular}{|c|c|c|c|c|c|c|c|c|}
\hline \multicolumn{9}{|c|}{ Panel A: Decile Portfolios } \\
\hline & \multicolumn{4}{|c|}{ without screening } & \multicolumn{4}{|c|}{ with screening } \\
\hline & cum. ret & $52 \mathrm{HR}$ & \multicolumn{2}{|c|}{$52 \mathrm{HR}$ - cum. ret } & cum. ret & $52 \mathrm{HR}$ & \multicolumn{2}{|c|}{$52 \mathrm{HR}$ - cum. ret } \\
\hline P1 & 13.38 & 15.14 & 1.75 & $(4.67)$ & 4.42 & 4.85 & 0.43 & $(2.10)$ \\
\hline $\mathrm{P} 2$ & 8.27 & 9.58 & 1.31 & $(4.32)$ & 3.96 & 4.70 & 0.75 & $(3.09)$ \\
\hline P3 & 6.55 & 7.64 & 1.09 & $(4.13)$ & 3.72 & 4.24 & 0.52 & $(2.88)$ \\
\hline $\mathrm{P} 4$ & 5.66 & 6.47 & 0.81 & $(3.64)$ & 3.49 & 3.74 & 0.24 & $(1.17)$ \\
\hline P5 & 5.15 & 5.42 & 0.27 & $(1.26)$ & 3.22 & 3.44 & 0.22 & $(1.26)$ \\
\hline P6 & 4.55 & 4.73 & 0.18 & $(1.14)$ & 3.04 & 3.12 & 0.08 & $(0.54)$ \\
\hline P7 & 4.29 & 4.03 & -0.26 & $(-1.89)$ & 2.81 & 2.87 & 0.06 & $(0.41)$ \\
\hline P8 & 4.43 & 3.46 & -0.97 & $(-4.06)$ & 2.90 & 2.55 & -0.34 & $(-2.00)$ \\
\hline P9 & 4.62 & 3.00 & -1.62 & $(-5.22)$ & 3.11 & 2.15 & -0.96 & $(-3.19)$ \\
\hline $\mathrm{P} 10$ & 5.21 & 2.69 & -2.52 & $(-4.57)$ & 3.28 & 2.20 & -1.09 & $(-2.29)$ \\
\hline $\begin{array}{c}\mathrm{P} 1-\mathrm{P} 10 \\
\mathrm{t} \text { value }\end{array}$ & $\begin{array}{c}8.17 \\
(4.34)\end{array}$ & $\begin{array}{c}12.44 \\
(5.50)\end{array}$ & 4.27 & $(4.94)$ & $\begin{array}{c}1.14 \\
(1.00)\end{array}$ & $\begin{array}{c}2.65 \\
(2.27)\end{array}$ & 1.52 & $(2.38)$ \\
\hline \multicolumn{9}{|c|}{ Panel B: 30, 40, 30\% Portfolios } \\
\hline & \multicolumn{4}{|c|}{ without screening } & \multicolumn{4}{|c|}{ with screening } \\
\hline & cum. ret & 52HR & \multicolumn{2}{|c|}{$52 \mathrm{HR}$ - cum. ret } & cum. ret & $52 \mathrm{HR}$ & \multicolumn{2}{|c|}{$52 \mathrm{HR}-\mathrm{cum}$} \\
\hline P1 & 9.34 & 10.72 & 1.37 & $(5.46)$ & 4.03 & 4.60 & 0.57 & $(3.14)$ \\
\hline $\mathrm{P} 2$ & 4.91 & 5.16 & 0.25 & $(2.24)$ & 3.14 & 3.29 & 0.15 & $(1.53)$ \\
\hline P3 & 4.75 & 3.06 & -1.70 & $(-4.96)$ & 3.10 & 2.32 & -0.78 & $(-2.83)$ \\
\hline $\begin{array}{l}\mathrm{P} 1-\mathrm{P} 3 \\
\mathrm{t} \text { value }\end{array}$ & $\begin{array}{c}4.59 \\
(3.83)\end{array}$ & $\begin{array}{c}7.66 \\
(5.68)\end{array}$ & 3.07 & $(5.27)$ & $\begin{array}{c}0.94 \\
(1.30)\end{array}$ & $\begin{array}{c}2.28 \\
(2.97)\end{array}$ & 1.35 & $(3.02)$ \\
\hline
\end{tabular}




\subsection{Double Sorted Portfolios}

Table 3 presents results from the double-sorting procedures designed to identify which of the two variables, 11-month cumulative returns or 52HR, has the stronger predictive power for January returns. The table indicates that 52HR has the stronger residual predictive power for January returns in both the unscreened and the screened samples.

Panel A of Table 3 demonstrates that, in the unscreened sample, the January profit based on the 52HR sorting within each cumulative return quintile is positive and statistically significant. January profit is largest for loser stocks (quintile 1), equal to 12.78 percent with a t-statistic of 5.48. The fact that the 52HR generates positive and statistically significant January profits in each of the cumulative return quintiles indicates that 52HR possesses residual predictive power for the January effect despite being first sorted by cumulative return.

Panel B of Table 3 reveals contrasting results. The January profits based first on 52HR and then, within each quintile, on cumulative returns are positive and statistically significant only in the first quintile (stocks with the lowest prior year 52-week high ratio) and are negative and statistically significant for all other quintiles. The fact that the January profit for quintile 1 of Panel B is less than that in quintile 1 of Panel A indicates that cumulative returns have less residual predictive power for January profit than does 52HR within the loser quintile.

The double sorting procedure reveals that the residual predictive power is smaller and that it contributes negatively to January profits in quintiles 2 through 5 . January profits for these quintiles are negative, indicating that cumulative returns lose residual predictive power for January profit and that cumulative returns generate losses for investors using cumulative return sorting within 52HR quintiles. Therefore, within these 52HR quintiles (quintiles 2 through 5), cumulative returns reveal the existence of momentum rather than January return reversal.

We also formally test the above argument by calculating the time-series average difference in January profit between the two double-sorting procedures. These results are in Panel $\mathrm{C}$ of Table 3. This difference is positive and statistically significant for all quintiles, from 6.99 percent with t-statistic 6.03 for quintile 1 , to 6.48 percent with t-statistic 5.32 for quintile 5 .

The results of the double sorting procedure displayed in Panels D, E and F of Table 3 reaffirm the results in Panels A, B and C by demonstrating that 52HR retains dominant predictive power for January profits even after small and low priced stocks are excluded. Panel D reveals that the January profit based on the 52HR sorting is positive for all quintiles, and statistically significant for all quintiles except quintile 1. Panel E shows that January return profit based on cumulative returns sorting, within each 52HR quintile, is negative and marginally statistically significant in quintiles 1 and 5, and insignificant in quintiles 2, 3 and 4. Panel $\mathrm{F}$ demonstrates that the time-series average difference in January profit between 52HR and cumulative returns is positive and statistically significant for all quintiles, from 2.33 percent with t-statistic 2.96 for quintile 1 , to 2.82 percent with t-statistic 2.66 for quintile 5 .

The results of the double-sorting procedures in Table 3 indicate that 52HR has stronger residual predictive power than do cumulative returns for the January effect. While in Table 2 we saw that either of the two singlesorting procedures enabled a zero-dollar investment strategy to generate significant January profits, the results in Table 3 suggest that 52HR is driving these profits, not cumulative returns. We next adopt the Fama-MacBeth (1973) approach in order to further confirm this finding in a regression format. 
Table 3: Returns for Two-way Sorted Portfolios

This table presents January returns for double-sorted portfolios based on 11-month cumulative returns and 52HRs. We include all stocks in Panels A, B, and C and applied size-and-price screening in Panels D, E and F. In Panel A (B), stocks are first sorted into quintiles by 11 -month cumulative returns (52HRs) at the end of each November. Stocks in each quintile are then assigned to one of the five equal-size portfolios based on 52HRs (11-month cumulative returns). We repeat this procedure from 1960 to 2008. Averages of returns on the 25 portfolios and return differences between the lowest and highest 11-month returns (52HRs) portfolios within each 52HR (11-month return) quintiles and associated t-values are presented. Panel $\mathrm{C}$ shows the differences in returns between Panel A and Panel B and associated t-values.

Panels D, E and F show the same information, except that we applied the size-and-price screening in Panels D, E and F.

\begin{tabular}{|c|c|c|c|c|c|c|c|}
\hline \multicolumn{8}{|c|}{ Panel A: Sorted First by 11-month Return and then by 52 HR (without screening) } \\
\hline & 1 & 2 & 3 & 4 & 5 & & \\
\hline 1(low 52HR) & 18.68 & 10.16 & 8.38 & 7.73 & 7.88 & 10.79 & $(4.34)$ \\
\hline 2 & 12.60 & 6.89 & 5.44 & 4.92 & 5.44 & 7.16 & $(4.01)$ \\
\hline 3 & 9.23 & 5.43 & 4.53 & 3.82 & 4.32 & 4.91 & $(3.82)$ \\
\hline 4 & 8.19 & 4.82 & 3.37 & 2.98 & 3.64 & 4.55 & (3.37) \\
\hline 5(high 52HR) & 5.89 & 3.28 & 2.54 & 2.33 & 3.18 & 2.71 & $(2.42)$ \\
\hline$(1)-(5)$ & 12.78 & 6.88 & 5.84 & 5.40 & 4.70 & & \\
\hline t-stat & $(5.48)$ & $(6.07)$ & $(6.24)$ & $(6.27)$ & $(5.23)$ & & \\
\hline
\end{tabular}

Panel B: Sorted First by 52 HR and then by 11-month Return (without screening)

\begin{tabular}{|c|c|c|c|c|c|c|c|}
\hline & $\begin{array}{c}1 \\
\text { (low 52HR) } \\
\end{array}$ & 2 & 3 & 4 & $\begin{array}{c}5 \\
\text { (high 52HR) } \\
\end{array}$ & \multicolumn{2}{|c|}{ (1) - (5) } \\
\hline 1(low cum. ret) & 17.44 & 6.50 & 4.26 & 3.03 & 2.21 & 15.23 & $(5.34)$ \\
\hline 2 & 11.78 & 6.26 & 4.59 & 3.36 & 2.39 & 9.39 & (5.66) \\
\hline 3 & 9.96 & 6.65 & 4.99 & 3.55 & 2.58 & 7.38 & $(5.35)$ \\
\hline 4 & 11.06 & 7.62 & 5.27 & 4.02 & 3.11 & 7.94 & $(5.55)$ \\
\hline 5(high cum. ret) & 11.65 & 8.24 & 6.25 & 4.77 & 3.99 & 7.66 & $(5.30)$ \\
\hline$(1)-(5)$ & 5.79 & -1.75 & -1.99 & -1.74 & -1.78 & & \\
\hline t-stat & $(3.29)$ & $(-2.39)$ & $(-3.07)$ & $(-2.39)$ & $(-2.49)$ & & \\
\hline \multicolumn{8}{|c|}{ Panel C: Difference between Panels A and B } \\
\hline \multirow{3}{*}{1} & 1 & 2 & 3 & 4 & 5 & & \\
\hline & 1.23 & 3.66 & 4.12 & 4.70 & 5.67 & & \\
\hline & $(3.87)$ & $(5.46)$ & $(6.18)$ & $(5.65)$ & $(5.39)$ & & \\
\hline \multirow{2}{*}{2} & 0.82 & 0.63 & 0.84 & 1.56 & 3.05 & & \\
\hline & $(1.88)$ & $(2.47)$ & $(3.23)$ & $(3.74)$ & $(4.68)$ & & \\
\hline \multirow{2}{*}{3} & -0.74 & -1.22 & -0.46 & 0.26 & 1.74 & & \\
\hline & $(-1.93)$ & $(-3.67)$ & $(-2.42)$ & $(1.34)$ & $(3.78)$ & & \\
\hline \multirow{2}{*}{4} & -2.86 & -2.80 & -1.90 & -1.05 & 0.53 & & \\
\hline & $(-5.33)$ & $(-5.80)$ & $(-4.39)$ & $(-3.67)$ & (1.90) & & \\
\hline \multirow{2}{*}{5} & -5.76 & -4.97 & -3.71 & -2.44 & -0.81 & & \\
\hline & $(-6.02)$ & $(-5.77)$ & $(-4.60)$ & $(-4.04)$ & $(-3.41)$ & & \\
\hline$(1)-(5)$ & 6.99 & 8.63 & 7.83 & 7.14 & 6.48 & & \\
\hline t-stat & $(6.03)$ & (5.99) & $(5.59)$ & $(5.14)$ & $(5.32)$ & & \\
\hline \multicolumn{8}{|c|}{ Panel D: Sorted First by 11-month Return and then by 52HR (with screening) } \\
\hline & $\begin{array}{c}1 \\
\text { (low cum. ret) }\end{array}$ & 2 & 3 & 4 & $\begin{array}{c}5 \\
\text { (high cum. ret) }\end{array}$ & \multicolumn{2}{|c|}{$(1)-(5)$} \\
\hline 1(low 52HR) & 4.35 & 4.96 & 4.49 & 4.06 & 4.14 & 0.21 & $(0.20)$ \\
\hline 2 & 4.81 & 4.28 & 3.43 & 3.55 & 3.56 & 1.25 & $(1.24)$ \\
\hline 3 & 4.41 & 3.45 & 3.18 & 2.57 & 3.01 & 1.40 & (1.55) \\
\hline 4 & 4.13 & 2.97 & 2.56 & 2.22 & 2.60 & 1.53 & (1.72) \\
\hline 5(high 52HR) & 3.24 & 2.39 & 1.98 & 1.85 & 2.61 & 0.63 & $(0.79)$ \\
\hline$(1)-(5)$ & 1.11 & 2.57 & 2.51 & 2.21 & 1.53 & & \\
\hline t-stat & (1.24) & (3.32) & $(3.55)$ & $(3.16)$ & $(2.26)$ & & \\
\hline
\end{tabular}


Table 3: Continued

\begin{tabular}{|c|c|c|c|c|c|c|c|}
\hline \multicolumn{8}{|c|}{ Panel E: Sorted First by 52 HR and then by 11-month Return (with screening) } \\
\hline & $\begin{array}{c}1 \\
\text { (low 52HR) }\end{array}$ & 2 & 3 & 4 & $\begin{array}{c}5 \\
\text { (high 52HR) }\end{array}$ & \multicolumn{2}{|c|}{$(1)-(5)$} \\
\hline 1(low cum. Ret) & 4.13 & 3.45 & 2.66 & 2.37 & 1.69 & 2.44 & $(2.04)$ \\
\hline 2 & 4.89 & 3.99 & 2.98 & 2.41 & 1.84 & 3.05 & $(3.04)$ \\
\hline 3 & 4.60 & 3.94 & 3.39 & 2.62 & 2.07 & 2.52 & $(3.02)$ \\
\hline 4 & 4.92 & 4.27 & 3.63 & 2.95 & 2.40 & 2.52 & $(2.72)$ \\
\hline 5(high cum. ret) & 5.35 & 4.30 & 3.73 & 3.22 & 2.99 & 2.37 & $(2.56)$ \\
\hline$(1)-(5)$ & -1.22 & -0.85 & -1.07 & -0.85 & -1.30 & & \\
\hline t-stat & $(-1.77)$ & $(-1.35)$ & $(-1.41)$ & $(-1.08)$ & $(-1.83)$ & & \\
\hline \multicolumn{8}{|c|}{ Panel F: Difference between Panels E and F } \\
\hline & 1 & 2 & 3 & 4 & 5 & & \\
\hline & 0.22 & 1.51 & 1.83 & 1.69 & 2.45 & & \\
\hline 1 & $(1.22)$ & (3.10) & (3.09) & $(2.35)$ & $(2.71)$ & & \\
\hline & -0.08 & 0.29 & 0.45 & 1.14 & 1.72 & & \\
\hline 2 & $(-0.44)$ & (1.44) & (1.58) & $(3.56)$ & $(2.70)$ & & \\
\hline & -0.19 & -0.49 & -0.20 & -0.05 & 0.94 & & \\
\hline 3 & $(-0.72)$ & $(-2.45)$ & $(-1.00)$ & $(-0.30)$ & $(2.13)$ & & \\
\hline & -0.79 & -1.31 & -1.07 & -0.73 & 0.20 & & \\
\hline 4 & $(-1.95)$ & $(-2.92)$ & $(-3.10)$ & $(-2.82)$ & $(0.74)$ & & \\
\hline 5 & -2.11 & -1.92 & -1.75 & -1.37 & -0.38 & & \\
\hline 5 & $(-3.06)$ & $(-2.45)$ & $(-2.29)$ & $(-2.33)$ & $(-1.61)$ & & \\
\hline$(1)-(5)$ & 2.33 & 3.43 & 3.58 & 3.06 & 2.84 & & \\
\hline t-stat & $(2.96)$ & $(2.83)$ & $(2.77)$ & $(2.47)$ & (2.66) & & \\
\hline
\end{tabular}

\subsection{Fama-MacBeth Regressions}

Table 4 presents results of Fama-MacBeth style cross-sectional regressions for both unscreened and screened samples. In Panel A of Table 4 we present results for the unscreened sample where, in columns 1 through 3 , December returns and size $\left(R_{i t-1}\right.$ and $\left.\ln \left(s i z e_{i t-1}\right)\right)$ are excluded, and in columns 4 through 6 these variables are included. This comparison allows for observation of the impact of monthly return reversal and firm size on the January effect.

Columns 1 and 2 of Panel A can be viewed as a replication, in regression format, of those in Table 2. This approach enables us to observe separately the marginal effect of winner and loser portfolios on January returns, which is not possible in Table 2. In column 1, we include only winner and loser dummy variables based on the cumulative returns sorting strategy. The coefficient of the winner dummy is negative but statistically insignificant, indicating that winner portfolios do not contribute to the January effect. However, the coefficient of the loser dummy is positive and statistically significant, indicating that, based on the cumulative returns sorting strategy, loser portfolios contribute to the January effect. The difference between the coefficients for the loser and winner dummy variables is positive and statistically significant, and can be viewed as the January profit for the 30-40-30 portfolio sorting procedure when using cumulative returns, confirming the results in Table 2 . The intercept is 5.12 percent, with a t-statistic of 5.55, indicating strong overall market performance in January despite controlling for preceding year cumulative returns. This result seems puzzling and might be of interest for future research.

The results in column 2 are based on winner and loser dummy variables from the 52HR sorting procedure and, while similar to those in column 1, exhibit coefficients and t-values of a greater magnitude. Consistent with results in Table 2 showing that the January profit based on 52HR is greater than that based on cumulative returns, we find that the difference in coefficients between loser and winner dummy variables is greater than that in column 1 (7.41 percent with t-value 5.69 versus 4.71 percent with t-value 4.03$)$.

However, unlike in column 1 where the coefficient of the loser dummy is positive and statistically significant but that of winner dummy is negative and insignificant, in column 2 the coefficients of both loser and winner dummy variables attain statistical significance with appropriate signs. This implies that, under the 52HR 
sorting procedure, winner and loser portfolios have symmetric effects on the January reversal, while such effects under cumulative returns are not symmetric.

In column 3, all dummy variables and differences in coefficients between loser and winner dummy variables are included in the regression. These results indicate that, when included jointly, cumulative returns lose predictive power and 52HR assumes the dominant role in explaining the January effect. First, the difference in coefficients between loser and winner dummy variables under the cumulative returns sorting strategy becomes negative and statistically insignificant, indicating that portfolios based on this sorting strategy do not explain the January effect when we control for 52HR. Second, loser dummy variables under cumulative returns sorting become insignificant, whereas these variables were the driving force for January profit in Table 2. At the same time, winner dummy variables based on cumulative returns sorting change sign to positive and become marginally significant (coefficient of 0.59 percent with t-value 1.65). This is consistent with results in Panel B of Table 3 where cumulative returns within 52HR quintiles generate momentum profits in all quintiles other than the first. Overall, the results in Column 3of Table 4 suggest that 52HR has predictive power for January returns and that the observed predictive power of cumulative returns in Table 2 is a consequence of its correlation with 52HR.

In columns 4 through 6 we estimate the same regressions as in columns 1 though 3 except that December return and size are now included. These regressions allow us to determine the extent to which the portfolios based on prior-year cumulative returns and 52HR generate January returns after controlling for monthly return reversal and firm size. A number of important findings from these regressions contribute to greater understanding of seasonality in return patterns.

First, monthly return reversal and firm size are powerful determinants of January returns. In all three specifications (4 though 6), the coefficients of December return and size, $R_{i t-1}$ and $\ln \left(s_{i z} e_{i t-1}\right)$, respectively, have negative and statistically significant coefficients, indicating that stocks with poor performance and small size in December, on average, yield greater returns in January. The coefficient of the December return is -16.47 percent with a t-value of -7.74 in column 4 , and -16.56 percent with $t$-value -8.07 in the fully specified regression 6 . The coefficient of the size is -1.51 percent with a t-value of -9.63 in column 4 , and -1.32 percent with $t$-value -9.32 in column 6.

Second, although the inclusion of December return and size reduces the magnitude of the coefficients, as compared with columns 1 through 3, 52HR retains its explanatory power for the January effect while the predictive power of cumulative return disappears. The fully specified regression in column 6 shows that the coefficient of the difference in coefficients between loser and winner dummy variables under the 52HR sorting strategy is positive and statistically significant while the coefficient of the difference in coefficients under cumulative returns is positive and insignificant (3.97 with t-value 4.46, and 0.25 with t-value 0.46 , respectively). This indicates that, while December returns and size are unambiguously powerful in explaining January returns, it is 52HR, rather than cumulative returns, that has predictive power for these returns.

In Panel B of Table 4 we conduct the same regressions as in Panel A, except that here we use the screened sample. Our results indicate that, in this sample, the January profit based on cumulative returns sorting disappears (it is statistically insignificant in columns 1,3,4 and 6), while profit based on 52HR remains statistically significant (in columns 2, 3,5 and 6). These results suggest that eliminating stocks priced below $\$ 5$ at the end of the formation period and those with market capitalization in the smallest NYSE decile is sufficient to make the January profit based on cumulative return sorting insignificant. However, this sample restriction does not eliminate the statistical significance of the January profit based on 52HR. Additionally, the January profit based on 52HR derives symmetrically from both winner and loser portfolios, as indicated by the positive and statistically significant coefficients for the dummy variables of winner portfolios and negative and significant coefficients for dummy variables of loser portfolios in columns 3 and 6 of Panel B. Together these results suggest that, if measured by 52HR, the January effect is not restricted to small and low-priced stocks.

In Panel $\mathrm{C}$ of Table 4, we present results of regressions for both unscreened and screened samples where we include December in the portfolio formation period. These regressions allow us to test whether the weaker predictive power of cumulative returns observed throughout our tests was a consequence of the exclusion of December from the portfolio formation period. Our results suggest that this is not the case. 
In Panel $\mathrm{C}$, the difference in coefficients between loser and winner dummy variables based on cumulative returns is both greater than and more statistically significant than those in Panels A and B, indicating that inclusion of December in the portfolio formation period enhances the predictive power of the cumulative returns; we find the same result for 52HR. The coefficients of the difference between loser and winner dummy variables based on 52HR in Panel C are greater than those in Panels A and B, indicating that inclusion of December enhances the predictive power of 52HR as well. However, columns 3 and 6 of Panel $\mathrm{C}$ demonstrate that the predictive power of cumulative returns disappears when this variable is included jointly with 52HR. Therefore, the fact that cumulative returns have weaker predictive power for the January effect is not a consequence of the fact that December was excluded from the portfolio formation period. Furthermore, inclusion of December enhances predictive power for both cumulative returns and 52HR, possibly due to monthly return reversal.

Table 4: Fama-MacBeth Type Regression

The basic functional form of the regression equation is

$$
R_{i t}=b_{0 t}+b_{1 t} R_{i t-1}+b_{2 t} \ln \left(\text { size }_{i t-1}\right)+b_{3 t} R W_{i t-D}+b_{4 t} R L_{i t-D}+b_{5 k t} 52 H R W_{i t-D}+b_{6 k t} 52 H R L_{i t-D}+e_{i t} .
$$

We conduct the cross-sectional regression for each January. In Panels A and B, $D=1$ so that we allow one-month gap between portfolio formation period and the following January, and in Panel C, $D=0$ so that there is no gap. $R_{i t}$ is January return for stock $i$ and $R_{i t-1}$ stock $i$ 's previous December return. $\ln \left(\right.$ size $\left._{i t-1}\right)$ is the natural logarithm of stock $i$ 's market capitalization at the end of December. $R W_{i t-D}$ is a dummy variable that equals one if stock $i$ 's cumulative return (January through November if $D=1$ and January through December if $D=0$ ) in the previous year is in the top $30 \%$, and is zero otherwise; $R W_{i-D}$ takes one if stock $i$ 's cumulative returns over the same period is in the bottom $30 \%$ and takes zero otherwise; $52 H R W_{i-D}$ takes one if stock $i$ 's $52 \mathrm{HR}$ belongs to top $30 \%$ at the end November when $D=1$ (December if $D=0$ ) and takes zero otherwise; $52 H R L_{i-D}$ takes one if stock $i$ 's $52 \mathrm{HR}$ belongs to bottom $30 \%$ and zero otherwise.

For each January, regression equation is estimated and the differences in the coefficient estimates between loser and winner dummies are calculated. The tables present time-series averages and associated t-values for coefficients and difference in coefficients between loser and winner dummies.

In Panels A and C, we include all stocks in the sample and we exclude small and low priced stocks from the sample in Panel B. In Columns 1 through 3 of Panels A and B and in the entire Panel C, we do not control for December returns and firm size, while we control for them in Columns 4 through 6 in Panels A and B.

Columns 1, 2, 4, and 5 of all Panels include dummy variables from only one variable, cumulative return or 52HR, but Columns 3 and 6 include dummy variables from both variables.

\begin{tabular}{|c|c|c|c|c|c|c|}
\hline \multicolumn{7}{|c|}{ Panel A: without screening } \\
\hline & \multicolumn{3}{|c|}{ Without Dec. Return and Size } & \multicolumn{3}{|c|}{ With Dec. Return and Size } \\
\hline & Return & $52 \mathrm{HR}$ & $\begin{array}{c}\text { Return, } \\
52 \mathrm{HR}\end{array}$ & Return & $52 \mathrm{HR}$ & $\begin{array}{c}\text { Return, } \\
52 \mathrm{HR}\end{array}$ \\
\hline Intercept & $\begin{array}{c}5.12 \\
(5.55)\end{array}$ & $\begin{array}{c}5.54 \\
(5.63)\end{array}$ & $\begin{array}{c}5.26 \\
(5.52)\end{array}$ & $\begin{array}{c}22.12 \\
(10.28)\end{array}$ & $\begin{array}{c}20.52 \\
(10.67)\end{array}$ & $\begin{array}{c}20.10 \\
(10.69)\end{array}$ \\
\hline $\mathrm{R}_{\mathrm{t}-1}$ & & & & $\begin{array}{l}-16.47 \\
(-7.74)\end{array}$ & $\begin{array}{l}-16.48 \\
(-7.91)\end{array}$ & $\begin{array}{l}-16.56 \\
(-8.07)\end{array}$ \\
\hline $\ln ($ size $)$ & & & & $\begin{array}{l}-1.51 \\
(-9.63)\end{array}$ & $\begin{array}{c}-1.34 \\
(-9.43)\end{array}$ & $\begin{array}{l}-1.32 \\
(-9.32)\end{array}$ \\
\hline Return Winner & $\begin{array}{l}-0.48 \\
(-1.09)\end{array}$ & & $\begin{array}{c}0.59 \\
(1.65)\end{array}$ & $\begin{array}{l}-0.18 \\
(-0.50)\end{array}$ & & $\begin{array}{c}0.32 \\
(0.97)\end{array}$ \\
\hline Return Loser & $\begin{array}{c}4.22 \\
(4.60)\end{array}$ & & $\begin{array}{c}0.53 \\
(1.22)\end{array}$ & $\begin{array}{c}2.50 \\
(3.57)\end{array}$ & & $\begin{array}{c}0.57 \\
(1.52)\end{array}$ \\
\hline 52HR Winner & & $\begin{array}{l}-2.23 \\
(-5.33)\end{array}$ & $\begin{array}{l}-2.28 \\
(-5.56)\end{array}$ & & $\begin{array}{c}-1.14 \\
(-3.18)\end{array}$ & $\begin{array}{c}-1.09 \\
(-3.26)\end{array}$ \\
\hline 52HR Loser & & $\begin{array}{l}5.18 \\
(5.35)\end{array}$ & $\begin{array}{c}4.84 \\
(5.79)\end{array}$ & & $\begin{array}{c}3.22 \\
(4.28)\end{array}$ & $\begin{array}{c}2.88 \\
(4.52)\end{array}$ \\
\hline $\begin{array}{l}\text { Loser - Winner } \\
\text { (Return) }\end{array}$ & $\begin{array}{c}4.71 \\
(4.03)\end{array}$ & & $\begin{array}{c}-0.07 \\
(-0.10)\end{array}$ & $\begin{array}{c}2.68 \\
(3.06)\end{array}$ & & $\begin{array}{c}0.25 \\
(0.46)\end{array}$ \\
\hline $\begin{array}{l}\text { Lower - Winner } \\
\text { (52HR) }\end{array}$ & & $\begin{array}{c}7.41 \\
(5.69)\end{array}$ & $\begin{array}{c}7.12 \\
(6.16)\end{array}$ & & $\begin{array}{c}4.36 \\
(4.27)\end{array}$ & $\begin{array}{c}3.97 \\
(4.46)\end{array}$ \\
\hline
\end{tabular}


Table 4 continued

\begin{tabular}{|c|c|c|c|c|c|c|}
\hline \multicolumn{7}{|c|}{ Panel B: with screening } \\
\hline & \multicolumn{3}{|c|}{ Without Dec. Return and Size } & \multicolumn{3}{|c|}{ With Dec. Return and Size } \\
\hline & Return & $52 \mathrm{HR}$ & $\begin{array}{l}\text { Return, } \\
52 \mathrm{HR}\end{array}$ & Return & $52 \mathrm{HR}$ & $\begin{array}{l}\text { Return, } \\
52 \mathrm{HR}\end{array}$ \\
\hline Intercept & $\begin{array}{c}3.25 \\
(4.20)\end{array}$ & $\begin{array}{c}3.43 \\
(4.05)\end{array}$ & $\begin{array}{c}3.45 \\
(4.28)\end{array}$ & $\begin{array}{l}13.03 \\
(6.75)\end{array}$ & $\begin{array}{l}12.81 \\
(7.06)\end{array}$ & $\begin{array}{l}12.44 \\
(6.99)\end{array}$ \\
\hline $\mathrm{R}_{\mathrm{t}-1}$ & & & & $\begin{array}{l}-9.85 \\
(-6.19)\end{array}$ & $\begin{array}{l}-9.87 \\
(-6.13)\end{array}$ & $\begin{array}{l}-10.11 \\
(-6.60)\end{array}$ \\
\hline $\ln ($ size $)$ & & & & $\begin{array}{l}-0.80 \\
(-6.28)\end{array}$ & $\begin{array}{l}-0.76 \\
(-6.57)\end{array}$ & $\begin{array}{c}-0.73 \\
(-6.28)\end{array}$ \\
\hline Return Winner & $\begin{array}{l}-0.23 \\
(-0.63)\end{array}$ & & $\begin{array}{c}0.29 \\
(0.78)\end{array}$ & $\begin{array}{l}-0.21 \\
(-0.60)\end{array}$ & & $\begin{array}{l}0.16 \\
(0.47)\end{array}$ \\
\hline Return Loser & $\begin{array}{c}0.78 \\
(1.78)\end{array}$ & & $\begin{array}{c}-0.38 \\
(-1.64)\end{array}$ & $\begin{array}{c}0.55 \\
(1.41)\end{array}$ & & $\begin{array}{c}-0.27 \\
(-1.24)\end{array}$ \\
\hline 52HR Winner & & $\begin{array}{l}-0.97 \\
(-3.17)\end{array}$ & $\begin{array}{l}-1.16 \\
(-3.46)\end{array}$ & & $\begin{array}{l}-0.81 \\
(-2.82)\end{array}$ & $\begin{array}{c}-0.93 \\
(-3.18)\end{array}$ \\
\hline 52HR Loser & & $\begin{array}{c}1.17 \\
(2.48)\end{array}$ & $\begin{array}{c}1.33 \\
(2.99)\end{array}$ & & $\begin{array}{c}0.79 \\
(1.89)\end{array}$ & $\begin{array}{c}0.90 \\
(2.30)\end{array}$ \\
\hline $\begin{array}{l}\text { Loser - Winner } \\
\text { (Return) }\end{array}$ & $\begin{array}{c}1.01 \\
(1.51)\end{array}$ & & $\begin{array}{c}-0.66 \\
(-1.25)\end{array}$ & $\begin{array}{c}0.76 \\
(1.26)\end{array}$ & & $\begin{array}{c}-0.43 \\
(-1.22)\end{array}$ \\
\hline $\begin{array}{l}\text { Lower - Winner } \\
(52 \mathrm{HR})\end{array}$ & & $\begin{array}{c}2.14 \\
(2.94)\end{array}$ & $\begin{array}{c}2.49 \\
(3.43)\end{array}$ & & $\begin{array}{c}1.60 \\
(2.44)\end{array}$ & $\begin{array}{l}1.83 \\
(4.07)\end{array}$ \\
\hline
\end{tabular}

\begin{tabular}{|c|c|c|c|c|c|c|}
\hline \multicolumn{7}{|c|}{ Panel C: Including Dec. Returns in Formation Period } \\
\hline & \multicolumn{3}{|c|}{ Without Screening } & \multicolumn{3}{|c|}{ With Screening } \\
\hline & Return & $52 \mathrm{HR}$ & $\begin{array}{l}\text { Return, } \\
52 \mathrm{HR}\end{array}$ & Return & $52 \mathrm{HR}$ & $\begin{array}{l}\text { Return, } \\
52 \mathrm{HR}\end{array}$ \\
\hline Intercept & $\begin{array}{c}4.99 \\
(5.45)\end{array}$ & $\begin{array}{c}5.29 \\
(5.45)\end{array}$ & $\begin{array}{c}5.01 \\
(5.37)\end{array}$ & $\begin{array}{c}3.16 \\
(4.02)\end{array}$ & $\begin{array}{c}3.49 \\
(4.15)\end{array}$ & $\begin{array}{c}3.50 \\
(4.30)\end{array}$ \\
\hline Return Winner & $\begin{array}{l}-0.78 \\
(-1.68)\end{array}$ & & $\begin{array}{c}0.33 \\
(0.89)\end{array}$ & $\begin{array}{l}-0.37 \\
(-0.96)\end{array}$ & & $\begin{array}{c}0.18 \\
(0.49)\end{array}$ \\
\hline Return Loser & $\begin{array}{c}5.01 \\
(5.01)\end{array}$ & & $\begin{array}{c}1.03 \\
(2.33)\end{array}$ & $\begin{array}{c}0.99 \\
(2.28)\end{array}$ & & $\begin{array}{c}-0.31 \\
(-1.24)\end{array}$ \\
\hline 52HR Winner & & $\begin{array}{l}-2.32 \\
(-5.45)\end{array}$ & $\begin{array}{l}-2.17 \\
(-5.52)\end{array}$ & & $\begin{array}{l}-1.40 \\
(-4.38)\end{array}$ & $\begin{array}{l}-1.49 \\
(-4.47)\end{array}$ \\
\hline 52HR Loser & & $\begin{array}{c}6.07 \\
(5.89)\end{array}$ & $\begin{array}{c}5.36 \\
(6.40)\end{array}$ & & $\begin{array}{c}1.27 \\
(2.69)\end{array}$ & $\begin{array}{c}1.40 \\
(3.18)\end{array}$ \\
\hline $\begin{array}{l}\text { Loser - Winner } \\
\text { (Return) }\end{array}$ & $\begin{array}{c}5.78 \\
(4.49)\end{array}$ & & $\begin{array}{c}0.70 \\
(1.05)\end{array}$ & $\begin{array}{c}1.37 \\
(1.93)\end{array}$ & & $\begin{array}{c}-0.49 \\
(-0.88)\end{array}$ \\
\hline $\begin{array}{l}\text { Lower - Winner } \\
(52 \mathrm{HR})\end{array}$ & & $\begin{array}{c}8.39 \\
(6.05)\end{array}$ & $\begin{array}{l}7.54 \\
(6.49)\end{array}$ & & $\begin{array}{c}2.67 \\
(3.61)\end{array}$ & $\begin{array}{c}2.90 \\
(3.98)\end{array}$ \\
\hline
\end{tabular}

\section{CONCLUSION}

We find that the ratios of November- or December-end price to the 52-week high have more significant predictive power for January reversals than do 11- or 12-month cumulative returns in the preceding year. Furthermore, cumulative returns lose predictive power for the January effect in Fama-MacBeth type regressions once we control for 52-week high ratios. 
Unlike the cumulative return case, we find that the January effect derives from poor performance of winning stocks as well as good performance of losing stocks when measured by 52-week high ratios. Also, the January effect is not restricted to small and low priced stocks if measured by 52-week high ratios, while the January effect disappears if we exclude small and low priced stocks and measure the effect using cumulative returns in the previous year. We believe our results are inconsistent with the tax-loss selling argument for the January effect and seem more consistent with window-dressing driven by fund holders' "anchoring bias" where fund holders regard the 52-week high as their reference price when they perceive a stock as a good or poor performer.

\section{ACKNOWLEDGEMENTS} alone.

We would like to thank Bruce Swensen and Jayen Patel for their valuable comments. All errors are ours

\section{AUTHOR INFORMATION}

Seung-Chan Park received a Ph.D. in Business Administration (Finance) from the University of Tennessee at Knoxville, and has been an Assistant Professor of Finance at Adelphi University since 2006. His research and teaching interests are in behavioral finance, anomalies in equity markets, firm valuation and investment analysis.

Sviatoslav A. Moskalev is Assistant Professor of Finance at Adelphi University. He joined Adelphi University in 2005 after receiving his Ph.D. in Finance from the Terry College of Business at the University of Georgia in Athens, GA. His research is in the area of international corporate finance with emphasis on foreign direct investment, crossborder mergers and acquisitions, cross-border joint ventures, law and empirical investments. At Adelphi, he has taught courses in corporate and international finance and international business.

\section{REFERENCES}

1. Badrinath, S. G. and W. G. Lewellen, 1991. Evidence on tax-motivated securities trading behavior, Journal of Finance 46, 369-382.

2. Banz, R. W., 1981. The relationship between return and market value of common stocks. Journal of Financial Economics 9, 3-18.

3. Bhardwaj, R. K. and L. D. Brooks, 1992. The January anomaly: Effects of low share price, transaction costs and bid-ask bias? Journal of Finance 47, 553-575.

4. Blume, M. E. and R. F. Stambaugh, 1983. Bias in computed returns: An application to the size effect. Journal of Financial Economics 12, 387-404.

5. Booth, D. G. and D. B. Keim: 2000, "Is There Still a January Effect?" in Keim, D. B. and W. T. Ziemba (eds.), Security Market Imperfections in Worldwide Equity Markets, (Cambridge University Press, New York), 169-178.

6. $\quad$ Branch, B., 1977. A tax loss trading rule. Journal of Business 50, 198-207.

7. Branch, B. and K. Chang, 1990. Low price stocks and the January effect. Quarterly Journal of Business and Economics 29, 90-118.

8. Brown, P., D. B. Keim, A. W. Kleidon and T. A. Marsh, 1983. Stock return seasonalities and the tax-loss selling hypothesis: Analysis of the arguments and Australian evidence. Journal of Financial Economics 12, $105-127$.

9. Chan, K. C., 1986. Can tax-loss selling explain the January seasonal in stock returns, Journal of Finance $41,1115-1128$.

10. Chang, Eric C. and Michael J. Pinegar, 1986. Return seasonality and tax-loss selling in the market for longterm government and corporate bonds, Journal of Financial Economics 17, 391- 415.

11. Chordia, Tarun and Lakshmanan Shivakumar, 2002. Momentum, Business Cycle Risk, and Time Varying Expected returns, Journal of Finance 57, 985-1019.

12. Chen, H. and V. Singal, 2004. All things considered, taxes drive the January effect. Journal of Financial Research 27, 351-372.

13. De Bondt, W. F. M. and R. Thaler, 1985. Does the stock market overreact? Journal of Finance 40, $793-$ 805 . 
14. De Bondt, W. F. M. and R. Thaler, 1987. Further evidence on investor overreaction and stock market seasonality. Journal of Finance 42, 557-581.

15. Dyl, Edward, 1977. Capital gains taxation and year-end stock market behavior, Journal of Finance 32, 165-175.

16. Dyl, Edward and Edwin Maberly, 1992. Odd-lot transactions around the turn of the year and the January effect, Journal of Financial and Quantitative Analysis 27, 591-604.

17. Fama, E. F. and K. R. French, 1993. Common risk factors in the returns on stocks and bonds, Journal of Financial Economics 33, 3-56.

18. Fountas, S. and Konstantinos, S., 2002. Emerging stock markets return seasonalities: The January effect and the tax-loss selling hypothesis, Applied Financial Economics 12, 291-299.

19. George, T. and Hwang, C., 2004. The 52-week high and momentum investing, Journal of Finance 59-5, 2145-2176.

20. Givoly, D. and Ovadia, A., 1983. Year-end induced sales and stock market seasonality, Journal of Finance 38, 171-185.

21. Grinblatt, Mark and Matti Keloharju, 2001. What makes investors trade, Journal of Finance 56, 589-616.

22. Gu, A. Y., 2003. The declining January effect: Evidence from the US equity markets, Quarterly Review of Economics and Finance 43, 395-404.

23. Gultekin, M. N. and N. B. Gultekin, 1983. Stock market seasonality: International evidence, Journal of Financial Economics 12, 469-481.

24. Haugen, R. A. and J. Lakonishok, 1988. The Incredible January Effect. (Dow Jones Irwin, Homewood, IL).

25. He, Jia, Ng Lilian and Qinghai Wang, 2004. Quarterly trading patterns of financial institutions, Journal of Business 77(3), 493-509.

26. Hensel, C. R. and W. T. Ziemba, 2000, "Anticipation of the January Small Firm Effect in the US Futures Markets", in: Keim, D. B. and W. T. Ziemba (eds.), Security Market Imperfections in Worldwide Equity Markets, (Cambridge University Press, New York), 179-202.

27. Ivkovic, Zoran, James Poterba, and Scott Weisbenner, 2005. Tax-motivated trading by individual investors, American Economic Review 95, 1605-1630.

28. Jegadeesh, Narasimhan and Sheridan Titman, 2001. Profitability of Momentum Strategies: An Evaluation Of Alternative Explanation, Journal of Finance 56, 699-720.

29. Jones, Charles, Douglas Pearce and Jack Wilson, 1987. Can tax-loss selling explain the January effect? A note, Journal of Finance 42, 453-461.

30. Keim, Donald, 1983. Size-related anomalies and stock return seasonality: Further empirical evidence, Journal of Financial Economics 12, 12-32.

31. Lakonishok, Josef, Andrei Shleifer, Richard Thaler, and Robert Vishny, 1991. Window dressing by pension fund managers, American Economic Review 81(2), 227-231.

32. Lakonishok, Josef and Seymour Smidt, 1986. Volume for winners and losers: Taxation and other motives for stock trading, Journal of Finance 41, 951-974.

33. Lo, A. and A. C. MacKinlay, 1990. When are contrarian profits due to stock market overreaction? Review of Financial Studies 3, 175-208.

34. Maxwell, William, 1998. The January effect in the corporate bond market: A systematic examination, Financial Management 27, 18-30.

35. Mehdian, S. and M. J. Perry, 2002. Anomalies in US equity markets: A reexamination of the January effect, Applied Financial Economics 12, 141-145.

36. Meier, Iwan and Ernst Schaumburg, 2004. Do funds window dress? Evidence for U.S. domestic equity mutual funds. Working paper, Northwestern University.

37. Musto, David, 1997. Portfolio disclosures and year-end price shifts, The Journal of Finance 52-4, 15631588 .

38. O'Barr, William and John Conley, 1992. Fortune and folly: The wealth and power of institutional investing. (Business One Irwin, Homewood, IL).

39. Odean, Terrance, 1998. Are investors reluctant to realize their losses, Journal of Finance 53, $1775-1798$.

40. Park, Seung-Chan, 2009. The moving average ratio and momentum, Working Paper, Adelphi University (forthcoming in the Financial Review).

41. Reinganum, Marc, 1983. The anomalous stock market behavior of small firms in January, Journal of Financial Economics 12, 89-104. 
42. Rendon, J. and W. T. Ziemba, 2005. Is the January effect still alive in the futures markets? Unpublished Working Paper, University of British Columbia, Vancouver, Canada.

43. Riepe, M. W., 1998. Is publicity killing the January effect? The Journal of Financial Planning 11, 64-70.

44. Ritter, Jay, 1988. The buying and selling behavior of individual investors at the turn of the year, Journal of Finance 43, 701-717.

45. Ritter, Jay and Navin Chopra, 1989. Portfolio rebalancing and the turn of the year effect, Journal of Finance 44, 149-166.

46. Roll, R., 1981. A possible explanation of the small firm effect, Journal of Finance 36, 879-888.

47. Roll, Richard, 1983. Vas ist das? The turn-of-the-year effect and the return premia of small firms, Journal of Portfolio Management 9, 18-28.

48. Rozeff, M. and W. Kinney, 1976. Capital market seasonality: The case of stock returns. Journal of Financial Economics 3, 379-402.

49. Siegel, J., 2007. Happy New Year. Wall Street Journal December 28, A13.

50. Sikes, S. A., 2008. The January effect and institutional investors: Tax-loss-selling or window-dressing? Working Paper, Duke University.

51. Slemrod, Joel, 1982. The effect of capital gains taxation on year-end stock market behavior, National Tax Journal 35, 69-77.

52. Starks, L., L. Yong and L. Zheng, 2006. Tax-loss selling and the January effect: Evidence from municipal bond closed-end funds. Journal of Finance 61(6), 3049-3067.

53. Stoll, H. R., R. E. Whaley, 1983. Transaction costs and the small firm effect, Journal of Financial Economics 12, 57-79.

54. Van den Bergh, W. M. and Roberto Wessels, 1985. Stock market seasonality and taxes: An examination of the tax-loss selling hypothesis, Journal of Business Finance and Accounting 12, 515-530. 